\title{
GCU
}

Glasgow Caledonian

University

University for the Common Good

\section{The nature and impact of urinary incontinence experienced by patients receiving community nursing services: a cross-sectional cohort study}

Cheater, Francine M.; Baker, Richard; Gillies, Clare; Wailoo, Allan; Spiers, Nicola; Reddish, Stuart; Robertson, Noelle; Cawood, Catherine

Published in:

International Journal of Nursing Studies

DOI:

10.1016/j.jijnurstu.2006.09.006

Publication date:

2008

Document Version

Author accepted manuscript

Link to publication in ResearchOnline

Citation for published version (Harvard):

Cheater, FM, Baker, R, Gillies, C, Wailoo, A, Spiers, N, Reddish, S, Robertson, N \& Cawood, C 2008, 'The nature and impact of urinary incontinence experienced by patients receiving community nursing services: a cross-sectional cohort study', International Journal of Nursing Studies, vol. 45, no. 3, pp. 339-351.

https://doi.org/10.1016/j.ijnurstu.2006.09.006

\section{General rights}

Copyright and moral rights for the publications made accessible in the public portal are retained by the authors and/or other copyright owners and it is a condition of accessing publications that users recognise and abide by the legal requirements associated with these rights.

Take down policy

If you believe that this document breaches copyright please view our takedown policy at https://edshare.gcu.ac.uk/id/eprint/5179 for details of how to contact us. 
THE NATURE AND IMPACT OF URINARY INCONTINENCE EXPERIENCED BY PATIENTS RECEIVING COMMUNITY NURSING SERVICES

SHORT TITLE:

URINARY INCONTINENCE EXPERIENCED BY PATIENTS RECEIVING COMMUNITY NURSING SERVICES 


\title{
THE NATURE AND IMPACT OF URINARY INCONTINENCE EXPERIENCED BY PATIENTS RECEIVING COMMUNITY NURSING SERVICES
}

\begin{abstract}
Aim

To define the nature and impact of urinary symptoms experienced by patients in receipt of community nursing services.
\end{abstract}

\section{Background}

World-wide, prevalence studies have shown that a significant proportion of the population experience urinary incontinence (UI) and/or related urinary symptoms. Nurses have played a pivotal role in the delivery of continence services yet little is known about the nature or impact of urinary symptoms experienced by patients in receipt of such care.

\section{Method}

The Leicestershire Urinary Symptoms Questionnaire, modified for self-completion, was administered to 1,078 patients identified with incontinence on 176 community nurses' caseloads. Information included type and severity of urinary symptoms, impact on quality of life, help with coping, use of continence products and health service resources.

\section{Results}

Nine hundred and ninety nine $(92.7 \%)$ patients (median age 79.0 years) responded. Most patients had UI between one and five years duration, women were more likely than men to have had long standing ( $>5$ years) symptoms and more than half the sample reported severe UI. Women were more likely than men to report symptoms of stress UI $(71.7 \%$ and $46.8 \%$ respectively) and urge UI ( $86.3 \%$ vs. $74.8 \%$ respectively). Half of the men and most women also experienced UI as a result of difficulty getting to, on or off, a toilet/commode. Men were 
more likely than women to report getting up three or more times a night to pass urine $(53.6 \%$ vs. $37.0 \%$ respectively).

Most patients reported that their symptoms had a significant impact on many aspects of quality of life, and $45.7 \%$ would be very dissatisfied to continue "the way they are now". Professional help appeared to be principally one of containment.

\section{Conclusion}

Current reforms in the UK (such as practice-based commissioning) and other western health systems provide prime opportunities to transform continence services to better meet the needs of all people who need them.

Key words: Urinary incontinence, urinary symptoms, community nursing, quality of life, quality of care. 


\section{What is already known about this topic?}

- Urinary incontinence and related lower urinary tract symptoms represent a major public health concern.

- Nurses have played a pivotal role in the development and delivery of continence services yet little is known about the nature and impact of urinary symptoms experienced by those receiving community nursing services.

\section{What this paper adds}

- Community nurses' median caseload size was 109 patients, of which a median of 42 $(38.5 \%)$ patients were identified with urinary incontinence.

- Many people living in the community in receipt of community nursing services experience two or more associated urinary symptoms which, in the majority, have a significant impact on many aspects of quality of life.

- Contrary to popular assumptions, most older patients in our study were not satisfied to "put up" with their urinary symptoms yet the findings suggested that professional help appears principally one of containment.

- Current reforms in the UK (such as practice-based commissioning) and other western health systems provide prime opportunities to transform continence services to better meet the needs of all people who need them. 
(Word count:4,969)

\section{THE NATURE AND IMPACT OF URINARY INCONTINENCE EXPERIENCED BY PATIENTS RECEIVING COMMUNITY NURSING SERVICES}

\section{INTRODUCTION}

It is recognised internationally that urinary incontinence (UI) and other lower urinary tract symptoms are common and represent a major public health concern (McGrother et al 2004, Hunskaar et al, 2004, Roberts et al, 1998). Recent research has suggested that approximately $30 \%$ of individuals aged 40 years and older living in the community in the UK have some form of clinically significant urinary symptoms (McGrother et al 2004, Perry et al, 2000). The prevalence of UI, defined as incontinent several times a month or more often, is estimated to be $14.9 \%$ (McGrother et al, 2004). Broadly similar levels of UI have been reported in Europe (Hunskaar et al, 2004, Malmsten et al 1997) and USA (Melville et al, 2005).

UI occurs more often in women, increases in both prevalence and severity with age (Melville et al, 2005, McGrother et al, 2004, Cheater and Castleden 2000, Perry et al 2000, Hunskaar et al, 2000) and is associated with decreased quality of life (Fultz et al, 2005, Perry et al, 2000, Roberts et al, 1998). The annual costs of UI to the National Health Service (NHS) have been estimated to be in the region of $£ 536$ million ( $\$ 945$ million) at 1999/2000 prices (Turner et al, 2004).

Across diverse western health care systems, nurses have played a pivotal role in the development and delivery of continence services (Milne et al, 2003). In the UK, providing care for people with UI constitutes a large part of the workload of community nurses (Audit Commission, 1999, Olver and Buckingham, 1997), namely district nurses and specialist 
health visitors (referred to as nurses in the remainder of the paper). Depending on how services are organised locally, patients with UI are referred to nurses by general practitioners and specialist nurses/continence advisors for first line and/or follow-up continence assessment and management. Secondary care doctors and nurses may also refer patients to the community nursing team for continence care in preparation for discharge. Where nurse-led community continence clinics exist, patients may also self refer. Yet in spite of the significant role community nurses play in delivering continence care, rigorous data defining the nature and impact of UI for patients in receipt of nursing services are lacking.

\section{THE STUDY}

\section{Aim}

The results presented in this paper define the nature and impact of urinary symptoms experienced by patients in receipt of community nursing services.

\section{Design}

The data reported here form part of a multi-centre randomised controlled trial evaluating two different approaches to improving continence care delivered by community nurses reported elsewhere (X et al). As part of the study, patients completed postal baseline and follow up UI symptoms questionnaires. In this paper we present and discuss the baseline questionnaire results on the nature and impact of UI reported by patients, all of whom were in receipt of community nursing services for the condition.

\section{Participants}

Thirteen NHS community providers serving populations ranging from 145,000 to 650,000 covering a mix of inner city/urban, suburban and rural localities in the English counties of East Anglia, East Midlands and West Midlands participated in the study. Study information and invitation letters were sent to all community nurses identified by personnel departments 
in each provider. Nurses were responsible for identifying all eligible patients on their caseloads and obtaining consent; new patients with UI referred to them during a six-week period as well as existing patients due for a six-month continence review were approached (all providers had a policy of bi-annual review). Eligible patients were required to be i) $\geq 16$ years; ii) incontinent of urine; and iii) competent to complete a postal questionnaire or provide consent for a carer to do so on their behalf. Patients with permanent indwelling urethral or supra-pubic urinary catheters were excluded.

From the 13 community providers, 270 (29.8\%) nurses initially approached agreed to participate. Nurses completed a brief postal questionnaire eliciting background details about themselves and their caseload. The median caseload size was 109 patients, of which a median of $42(38.5 \%)$ patients were identified with UI at the time of the study. Nurses reported a median of 2.5 new patient referrals for UI per month.

Of the initial 270 nurse participants, 18 subsequently withdrew (reasons e.g. left post, long term sick leave) and a further 76 failed to recruit any patients and were withdrawn, leaving 176 nurses attached to 157 GP practices in the study. Of a median of 9 (1-26) patients on nurses' caseloads who met the study inclusion criteria (described above), a median of 6 (1-22) patients consented. A total of 1,078 patients with UI (average of 6.9 patients per practice) identified by nurses, consented to participate.

The UI status of $1,020(94.6 \%)$ of the 1078 participating patients was confirmed by an independent review of the nursing records at baseline. The records were missing for 58 patients and their UI symptoms were verified through discussions with the relevant nurses and/or checking provider documentation relating to delivery of continence products. 


\section{Methods}

The nature and impact of UI symptoms experienced by patients was assessed by using the validated, interviewer-administered Leicestershire urinary symptoms questionnaire (LUSQ) (Shaw et al, 2002, Shaw et al 2004), developed as part of the Leicestershire Medical Research Council (MRC) Incontinence Study. We modified the LUSQ for self-completion in a postal questionnaire. Our target sample was older and frailer than the population based sample in which the LUSQ was used originally, so to reduce respondent burden we omitted a number of questions that were not directly relevant, and adapted several remaining questions for completion in the absence of an interviewer The modified questionnaire included 25 questions and the content covered urinary symptoms in the previous month, the impact of symptoms on dimensions of quality of life, help with coping, the use of continence products and health service resources (e.g. clinic/hospital visits) and demographic information. Most questions were fixed response format, with space for additional free text answers where appropriate. Symptom definitions (figure 1) adhered to the International Continence Society (ICS) standardization of lower urinary tract function at the time the study was undertaken (Abrams et al, 2002). Urinary incontinence was defined as "leaking urine when you don't mean to". The volume of urine loss was expressed in terms of "almost dry", "damp", "wet" (pad or underclothing wet) and "soaked" (pad saturated or outer clothing wet) which was found to be a better predictor of volume loss in English speaking people than other scales (Shaw et al, 2002, Sandvick et al 1993).

The modified questionnaire was piloted in a sample of 70 patients attending a nurse-led community continence clinic and was found to be acceptable, feasible for self completion and demonstrated good levels of face and content validity and internal consistency. In the main 
study, questionnaires with a covering letter and a reply-paid envelope were sent to patients' homes or in the case of a minority of patients, to the nursing or residential home in which they resided. Non-responders received reminders three weeks after the initial mailing with second reminders three to four weeks later.

\section{FIG. 1}

\section{Ethical Considerations}

The Multi-centre Research Ethics Committee (Cardiff, Wales) and Local Research Ethics Committees for each of the study sites approved the study. Potential participants were given oral and written information about the study. Written patient consent was obtained before participation in the study.

\footnotetext{
ANALYSIS

All data were entered into an SPSS (version 10) data base. Data were analysed using basic descriptive statistics (frequencies and percentages). Data were also analysed to assess for any gender differences. As the date were clustered (number of patients were assigned to each nurse) standard techniques such as Mann Whitney $\mathrm{U}$ or $\mathrm{X}^{2}$ tests were not used as these tests assume the data are independent. Instead gender differences were analysed by fitting multilevel models (what? and ref? ). The 5\% significance level was used throughout. The severity of UI was described in terms of frequency and volume of leakage as recommended by the ICS (Abrams et al, 2002) using the Sandvick index (Sandvick et al, 1993).
} 


\section{RESULTS}

Of the 1,078 baseline questionnaires administered, $886(82.2 \%)$ completed forms were returned after the first mailing and a further 113 on the second/third mailings reflecting a total response rate of $92.7 \%$. The sample comprised 768 women and 188 men with a median age of 79.0 years (Table 1). Information on gender was missing for a further 43 respondents. Thus the results are presented for the total sample $(n=999)$ and for the 768 female and 188 male respondents for whom gender was known.

\section{TABLE 1}

The majority of respondents rated their health as either fair or poor (Table 1) and 31.7\% reported they needed help with completing the questionnaire. Twelve (1.1\%) patients lived in nursing home facilities and the remainder lived in their own home.

\section{Duration and nature of symptoms}

The distribution of responses for urinary symptoms experienced in the previous month is shown for the whole sample and by gender in Table 2. Most respondents reported having UI between one and five years duration, with women significantly more likely than men to have had long standing (> 5 years) symptoms $(\mathrm{p}=0.009)$ (Table 2$)$.

\section{TABLE 2}

Using the Sandvick index (Sandvick et al, 1993) more than half of the men and women reported severe day-time and night time UI (Table 2). Over half the sample reported experiencing episodes of UI continuously or several times a day during the last month and the 
frequency of leakage was similar between men (63.4\%) and women (64.1\%). A similar proportion of the sample reported the volume of leakage equating to being "soaked" and "wet" in the previous month, with significantly fewer women than men reporting minimal leakage (damp: $25.8 \%$ vs $30.8 \%$, almost dry: $3.6 \%$ vs $5.8 \%$, $\mathrm{p}=0.001$ ) (Table 2 ).

Women were significantly more likely than men to report symptoms of stress UI $(71.7 \%$ and $46.8 \%$ respectively; $\mathrm{p}=<0.001)$ and symptoms of urge UI ( $86.3 \%$ vs. $74.8 \%$ respectively; $\mathrm{p}=0.01$ ) (Table 2). Approximately half of the men and women reported leaking urine without realising or feeling it happening in the previous month. Half of the men and two thirds of the women also experienced UI as a result of difficulty getting to, or getting on or off, a toilet or commode ("functional" UI); with significantly more women experiencing this type of urine loss $(\mathrm{p}=0.014)$. Approximately $10 \%$ of men and women reported the need to go to the toilet during the day on a half hourly basis while men were significantly more likely than women to report getting up three or more times a night to pass urine during the previous month (53.6\% vs. $37.0 \%$ respectively; $\mathrm{p}=0.016)$ (Table 2 ).

\section{Impact of urinary symptoms on dimensions of quality of life}

The distribution of responses for the impact of urinary symptoms on aspects of quality of life for the whole sample and by gender is shown in Table 3. There was no gender differences on any of the dimensions of quality of life measured. Ninety percent of the sample found their symptoms bothersome to some degree with $43.8 \%$ of men and $46.9 \%$ of women reporting their symptoms bothered them "a lot". About three quarters of the respondents experienced some degree of physical discomfort associated with UI, with about a quarter of men and women reporting "a lot" of discomfort. A third of male and female respondents found their 
symptoms interfered "a lot" with their daily activities while just under a quarter, of men and women reported that their ability to participate in social activities was affected. Eighteen point two percent of women and $22.4 \%$ of men also reported that their symptoms affected their relationships with other people "a lot", while urinary symptoms affected the quality of sleep "a lot" for over a third of men and women. Urinary symptoms also resulted in "a lot" of personal upset or distress for a third of women and just under a quarter of men. When asked how they would feel if they were to spend the rest of their life with their urinary symptoms over half of the female respondents and $41.4 \%$ of the male respondents reported they would feel very dissatisfied.

\section{TABLE 3}

\section{Help-seeking and Sources of Support for coping with UI symptoms}

In the previous six months $42(22.3 \%)$ male and $120(15.6 \%)$ female respondents had visited a hospital or clinic for investigations for their urinary symptoms while 11 (5.9\%) men and 28 (3.6\%) women had been admitted to hospital for treatment of UI.

Eighty-eight percent of the whole sample (83.5\% men and $93.7 \%$ women) had used absorbent products to manage their UI in the previous month and in the majority $(80.0 \%)$ continence aids were supplied and paid for by NHS/social services. Eighty-seven (8.7\%) respondents paid for UI products themselves. Men were significantly more likely than women to report receiving "a lot" of help coping with their UI symptoms from their partner (52.4\% vs. $20.5 \%$ respectively; $\mathrm{p}<0.001)$ (Table 4 ) although more than twice as many women $(44 \%)$ as men (15\%) were living alone (Table 1).

TABLE 4 
As patients were recruited from nurses' caseloads, all patients were known to be in contact with community health services at the time of the study. Excluding the not known/not applicable responses, approximately two thirds of the sample (66.7\% men and $64.4 \%$ women) identified the nurse and just under a half ( $46.3 \%$ men and $41.6 \%$ women) identified the doctor as helping them "a lot" to cope with their UI symptoms.

About a third of the whole sample had been in contact with the specialist nurse/continence advisor; of those who had been in contact, $58.6 \%$ men and $52.4 \%$ women reported receiving "a lot" of help coping with their UI symptoms.

\section{Limitations}

The interpretation of the results needs to take account of several potential limitations. We achieved a response rate of $93 \%$ from a patient sample with a median age of 79 years. This compares favourably with a $70 \%$ response rate achieved in an epidemiological community survey of symptomatic and non-symptomatic adults 40 years or over, employing the same urinary symptoms questionnaire (Perry et al, 2000). However, our sample was selective as patients were already known to have UI, were required to meet our study criteria and, to comply with the 1998 Data Protection Act, were recruited by nurses. Of the 906 nurses invited to participate, $270(29.8 \%)$ agreed to participate, $6.6 \%$ subsequently withdrew and a further $28 \%$ failed to recruit any patients (main reason given was lack of time) leaving 176 nurses in the trial. This potential selection bias is well recognised and is an inevitable consequence of voluntary participation in studies (Wilson et al, 2000).

Although independent checks verified the UI status of participants, we are less certain about the extent to which all eligible patients were approached. Although approximately two thirds 
of the eligible patients approached consented to participate, the extent to which nurses approached all patients on their caseloads who met the study criteria is unclear. Although some inter-nurse variability regarding patient recruitment can be attributed to differences in the prevalence of patients with UI on caseloads, it is also likely to be attributable to selection bias. Potential sampling bias may have been minimal though, as trends in the data on the nature and impact of UI can be extrapolated broadly to the results obtained in several community based prevalence studies of UI symptoms (McGrother et al, 2004, Perry et al, 2000, Swithinbank and Abrams 2000, Malmstem et al 1997, Thomas et al 1980). The age/sex profile of the patient sample was also broadly representative of community nurse caseloads nationally (Olver and Buckingham, 1997) and also reflects the fact that in comparison to men, women are more likely to experience UI (McGrother et al, 2004, Cheater and Castleden, 2000, Hunskaar et al, 2000). Most respondents assessed their health as fair or poor, and about a third required help with completing the questionnaire, findings that are likely to reflect the presence of co-existing chronic illness or disability that is common in a predominantly older, referred primary care population (Hunskaar et al, 1996).

Although patients were recruited from a diverse range of sites our sample was predominantly white with few patients from black or Asian ethnic minorities. Patients unable to read and write were also excluded if a carer was not available to complete the questionnaire on their behalf. The information sought relied on self report, which may have led to over-/underreporting of symptoms. This potential source of bias may have been negligible, however, as the LUSQ has been validated against objective criteria in the UK (Shaw et al 2002, Shaw et al 2004). The reason for the high level of missing data for the question on the impact of UI symptoms on relationships with other people is unclear. Most missing data to questions on impact on quality of life were from participants who relied on a carer to complete the 
questionnaire. In such cases, carers often recorded that they felt unable to answer such questions. If the LUSQ is to be administered as a postal survey in future studies, we recommend further piloting of the questions relating to dimensions of quality of life in circumstances where patients are unable to complete the questionnaire independently.

\section{DISCUSSION}

These findings define the nature and impact of UI symptoms experienced by patients in receipt of community nursing services in 13 NHS community providers in England. To our knowledge no comparable published data exist.

Our findings suggest that an average community nurse case load will comprise approximately a third of patients with UI, and of these patients, between one and two thirds will experience two or more associated urinary symptoms (e.g. nocturia, frequency, pain). From a work load perspective, this is likely to be an under estimate as we excluded patients with indwelling urethral and supra-pubic urinary catheters. Applying the same definitions for clinically significant thresholds for urinary symptoms used by McGrother et al (2004), we found that during the previous month over half of the patients identified with UI on nurses' caseloads experienced leakage (equating to being "soaked" or "wet") on a daily basis, the majority experienced symptoms of nocturia ( $\geq 2$ times a night or more often) and urge UI (strong desire to pass urine and leaking before reaching the toilet) and a third of men and women experienced frequency on an hourly basis or more often. Significantly more women than men reported symptoms of urge, stress and functional UI. Although the majority of men and women experienced nocturia, the symptom was more severe in men and likely to be 
associated with benign prostatic hyperplasia, a common condition in older men (Hollander and Diokno, 1996).

Almost half of the males in our sample reported leakage of urine during the last month when laughing, coughing, sneezing or exercising. Urodynamic investigations have shown that coughing and sneezing may provoke involuntary detrusor contractions (urge UI) (Moller et al, 2000) which may explain the large proportion of men who reported loss of urine on exertion. The co-existence of obstructive and irritative symptoms (urgency and urge UI) associated with benign prostatic hyperplasia is common (Hollander and Diokno 1996). Symptoms of urge and urge UI are common in older people (Hunskaar et al 2000, Cheater and Castleden 2000, 0'Dowd 1993) though data on the expected proportions of different types of UI in women and men are lacking (Hunskaar et al, 2000). Most women in our sample reported a profile of "mixed" UI symptoms (urge UI and stress UI) that is common in older females experiencing urinary symptoms (Thom 1998, McDowell et al, 1996).

The nature of the symptoms reported by patients in our study is based on a selected sample (i.e. a referred population with UI in receipt of community nursing services) and does not reflect the epidemiology of urinary symptoms of the general population. As severity of UI (frequency and volume of leakage) is related to help-seeking (McGrother et al, 2004, Hunskaar et al, 2000, Roe et al, 1999) the high proportion of the study sample reporting clinically significant symptoms is not unexpected. Nevertheless, for a number of symptoms the pattern is broadly comparable with the findings for older people in other studies undertaken in the general population in the UK and elsewhere (McGrother et al, 2004, Perry et al, 2000, Swithinbank and Abrams 2000, Malmstem et al 1997, Thomas et al 1980). 
Incidence rates for UI increase with age (Melville et al, 2005, McGrother et al, 2004, Cheater and Castleden 2000) and remission rates are notably higher in men than women (McGrother et al, 2004). This may partially explain why more women experienced UI symptoms for significantly longer ( $>$ five years) than men in our study. There is also some evidence that men seek health care for their urinary symptoms earlier than women, possibly because they may possess less knowledge about ways to self-manage symptoms, for example, through using absorbent incontinence products (Teunissen and Largo-Janssen 2004, Roberts et al, 1998).

Measurement of the frequency and severity of symptoms is limited without also establishing impact on quality of life (Abrams et al, 2002). The severity and impact ("bothersomeness") of urinary symptoms are key factors influencing whether or not professional help is sought (McGrother et al 2004, Roberts et al, 1998, Roe et al, 1999). Most respondents in our sample reported finding their symptoms bothersome to some degree, supporting the results of other studies that have shown that the most bothersome symptoms are predominantly associated with storage, including UI (McGrother et al, 2004, Peters et al 1997). The dimensions of quality of life asked about related to physical discomfort, interference with daily activities, impact on social life and relationships, effect on quality of sleep and emotional responses to UI symptoms. Taking into account the high proportion of missing data for some quality of life related questions, UI symptoms had an impact on some dimension of quality of life in the majority of respondents.

It is concerning that physical discomfort was experienced to some degree by most respondents. Older people are particularly vulnerable to the damaging effects of urine in contact with the skin which may cause dermatitis, infection and skin breakdown, particularly for those patients with heavy leakage who wear absorbent products (Ersser et al, 2005, Fantl 
et al, 1996), as was the case for most participants in our study. The extent to which nurses were aware of patients' discomfort is unclear, though recently it has been suggested that nurses may be neglecting routine skin care (Ersser et al, 2005)

Individuals' coping responses to living with UI may include changing daily routines, avoiding going out or contact with others as well as avoidance of outside leisure pursuits (Horrocks et al, 2004, Shaw 2001). There is little doubt that urinary symptoms had affected adversely, to some degree, most participants' ability to engage in domestic, personal and social activities.

Twice as many men as women reported receiving "a lot" of help with their UI symptoms from their partner, although almost three times more women than men were living alone. Living with a partner may offer emotional or practical support in the management of the condition, or in seeking services, but similarly, there is evidence that the spouse's UI symptoms may adversely affect the carer's quality of life (Peters et al 2004).

Participants were not asked which urinary symptoms bothered them the most but evidence from other studies suggests that the most bothersome symptoms are those that are most disruptive of everyday life (frequency, nocturia) or cause social embarrassment (e.g. urge UI) (Massolt et al, 2004, Teunissen and Largo-Janssen, 2004, Engstrom et al, 2004). Nocturia has been shown to have a negative impact on quality of life in both men (Peters et al 1997) and women (Massolt et al, 2004, Wagg 2004, Swithinbank et al 1999) and is associated with poor sleep quality, day time sleepiness (Aspland and Asberg 1992) and falls (Stewart et al 1992).Sleep disruption was a significant issue for both men and women, most of whom experienced clinically significant nocturia (the need to get up at night to pass urine $\geq 2$ times) and more than a third of women and over half of the men reporting the need to get up three or 
more times a night to pass urine. These findings reinforce the importance of enquiring routinely about sleep quality, as part of a comprehensive continence assessment.

Not all people with UI, however, find their symptoms bothersome or socially disabling (Perry et al, 2000). There is also evidence that older people may have low expectations of services or assume that UI is an evitable result of ageing (Horrocks et al, 2004, Shaw et al, 2001) and consequently, do not seek professional help. Further, the widely held view that UI is a common consequence of childbirth had led to a tendency to "normalize" the condition in women (Umlauf et al, 1996). In contrast, our findings suggested that many participants already in receipt of health services for their condition were not prepared to tolerate their symptoms in the future, even though most had experienced UI for longer than 12 months.

Although about two thirds and almost half of the sample respectively, reported they had received "a lot" of help coping with their urinary symptoms from the nurse and the doctor, their level of satisfaction with either their treatment or the outcomes of care is unclear. Most participants were using absorbent continence products to manage UI, supplied through their local community provider. Further, in the same study a baseline review of the nursing records reported elsewhere ( $\mathrm{X}$ et $\mathrm{al}$, in press), found that many of the participants had not had a comprehensive UI assessment and apart from continence products, such as absorbent pads, had rarely been offered targeted interventions such as life style advice, behavioural strategies, modification of fluid regimens and medication. In spite of evidence that UI symptoms are treatable or can be ameliorated to improve quality of life in many older people (Byles et al, 2005, Borrie et al 2002, Williams et al 2000, O'Brien et al, 1991) our findings suggest that the professional help many participants received reflected a policy of containment rather than active management. Similar concerns about the quality of continence care for older people 
have been highlighted elsewhere in the UK (Wagg et al, 2005) and in other developed countries such as the USA (Gnanadesigan et al, 2004, Watson et al, 2003, Brandeis et al, 1997) Canada (Milne and Moore, 2003) and Australia (St. John et al, 2002). Furthermore, a recent review of continence services world-wide, including the UK, has concluded that current models of provision are inconsistent and not adequately meeting the needs of service users (Milne and Moore, 2003).

Older people with UI in receipt of community nursing services often have complex health needs, including continence care, which may consume considerable nursing resources in terms of number of contacts and proportion of time spent with patients (Olver and Buckingham, 1997). The increase in the complexity and demands of community nursing workloads, and associated stressors, as a consequence of acute sector changes in the last 1015 years are well recognised in the UK (Rout 2000), Australia (Kemp et al, 2005) and the USA (Cashman et al, 2001). Expanding work load in the absence of equivalent resources create situations in which health professionals may have to make choices about what to do within the time available (Groenewegan and Hutten, 1995). There was evidence to suggest that nurses in our study had to make such decisions, for example, many cited insufficient time to complete a comprehensive continence assessment as one of the most common barriers to providing optimum care (reported elsewhere, $\mathrm{X}$ et al, in press). Similar findings have been reported elsewhere (Abbott and Hotchkiss, 2001). If people with UI are to receive the standards of continence care identified in the UK National Service Framework for Older People (Department of Health, 2001) and national/international guidelines (Vikrup et al, 2004, SIGN, 2004, Abrams et al, 2002, Fantl et al, 1996) community providers need to 
institute regular case mix assessment of nurse caseloads and ensure teams reflect the necessary skill mix.

\section{CONCLUSION}

The prevalence of urinary incontinence in the next two or three decades will increase as a consequence of the ageing demographic profile in the UK and other developed countries. Although many people with UI may not consider their symptoms bothersome, a significant proportion will seek professional help to treat or ameliorate their symptoms and improve their quality of life. Nurses will undoubtedly continue to have a major role in the promotion of continence but current models of service provision may be failing those who are most in need of such care. This may be partly the consequence of western health care reforms and policies to relocate many acute health care services to the community resulting in greater and more complex work loads for nurses working in the community. Current reforms in the UK (such as practice-based commissioning) and other western health systems provide prime opportunities to transform continence services to better meet the needs of all people who need them.

\section{Acknowledgement}

We are indebted to the patients and their carers, the nurses, including the "link nurses", managers and other NHS staff who participated in the study. Thanks are also due to Lynne Chapman, Eve Edwards and Sally Taylor who extracted data from the medical records. The project was funded by the UK NHS Research \& Development programme.

\section{References}


Abbott S. \& Hotchkiss J. (2001) It takes more than clinical effectiveness to change nursing practice: an unsuccessful project in the nurse promotion of urinary continence. Clinical Effectiveness in Nursing. 5:81-87.

Abrams P., Cardozo L., Khoury S. (2002) Incontinence. Second International Consultation on incontinence. Plymouth Distributors Ltd. http//www.continetorg/documents/ici_pdfs/Menus/main.pdf.

Abrams P., Cardozo L., Fall M., Griffiths D., Rosier P., Ulmstren U., Van Kerrebroeck P., Victor A. \& Wein A (2002). The standardisation of terminology of lower urinary tract function: report from the Standardisation Sub-committee of the International Continence Society. Neurourology \& Urodynamics. 21; 2:167-78.

Asplund R. \& Aberg H. (1993) Diurnal variation in the levels of antidiuretic hormone in the elderly. Journal of Internal Medicine. 229:131.

Audit Commission (1999). First assessment. A review of district nursing services in England and Wales. Audit Commission, London.

Borrie M.J., Bawden M., Speechley M., Kloseck M. (2002) Interventions led by nurse continence advisers in the management of urinary incontinence: a randomised controlled trial. Canadian Medical Association Journal. 166; 10:1267-73. 
Brandeis G.H., Baumann M.M., Hossain M., Morris J.N., Resnick N.M. (1997). The prevalence of potentially remediable urinary incontinence in frail older people: a study using the minimum data set. Journal of American Geriatrics Society. 42; 2:179-84.

Byles J.E., Chiarelli P., Hicker A.H., Bruin C., Cockburn J. \& Parkinson L. (2005). An evaluation of three community based projects to improve care for incontinence. International Urogynaecology. 16:29-33.

Cashman S.M., Lopez Bushness F., Farmer H. (2001) Community orientated primary care: a model for public health nursing. Journal of Politics, Policy and Law. 26:617-634.

Cheater F.M., Castleden C.M. (2000) Epidemiology and classification of urinary incontinence. Chapter in: Clinical Obstetrics and Gynaecology. Urinary Incontinence. (Cardoza L. Ed.), Balliere's Clinical Obstetrics and Gynaecology. London. pp. 183-205.

Department of Health (2001). National Service Framework for Older People. Department of Health, London.

Engstrom G., Walker-Engstrom M., Henningsohn L., Loof L. \& Leppert J. (2004) Prevalence of distress and symptom severity from the lower urinary tract in men: a population-based study with the DAN-PSS questionnaire. Family Practice. 21; 6: 616-22.

Ersser S.J., Getcliffe K., Voegeli S \& Regan S. (2005) A critical review of the interrelationship between skin vulnerability and urinary incontinence and related nursing intervention. International Journal of Nursing Studies. 42:823-835. 
Fantl JA, Newman DK, Colling J, et al. (1996) Urinary Incontinence in Adults: Acute and Chronic Management. Clinical Practice Guideline No. 2, 1996 Update. Rockville, MD: U.S. Department of Health and Human Services. Public Health Service, Agency for Health Care Policy and Research. AHCPR Publication No. 96-0682.

Fultz N.H., Jenkins K.R., Taylor D., Kabeto M.U. \& Langa K.M. (2005) The impact of own and spouse's urinary incontinence on depressive symptoms. Social Science \& Medicine.60; 11:2537-2548 (check as not in at the moment.

Gradadesignan N.M Saliba D., Roth C.P., Solomon D.H., Chang J.T., Schnelle J., Smith R., Shnelle J., Smith R., Shekelle P.G., Wenger N.S. (2004). The quality of care provided to vulnerable older community-based patients with urinary incontinence. Journal of the American Directors Association. 5; 3:141-6.

Groenewegan P.P. \& Hutten J.B.F. (1995) The influence of supply related characteristics on general practitioners' work load. Social Science \& Medicine. 40:348-58.

Hollander J.B. \& Diokno A.C. (1996) Prostatism: Benign prostatic hypertrophy. Urologic Clinics of North America. 23:75-86.

Horrocks S., Somerset M., Stoddart H. \& Peters T.J. (2004). What prevents older people from seeking treatment for urinary incontinence? A qualitative exploration of barriers to the use of community continence services. Family Practice. 21; 5:689-696. 
Hunskaar S., Lose G., Sykes D. \& Voss S. (2004) The prevalence of urinary incontinence in women in four European countries. British Journal of Urology International. 93:324-30.

Hunskaar S., Arnold E.P., Burgio K., Diokno A.C., Herzog A.R. \& Mallett V.T. (2000) Epidemiology and natural history of urinary incontinence. International Urogynecology Journal. 11:301-319.1

Hunskaar S., Seim A. \& Freeman T. (1996) The journey of incontinence women from community to university clinic: implications for selection bias, gatekeeper function and primary care. Family Practice. 14:363-368.

Kemp L.A., Harris E. \& Comino E.J. (2005) Chnages in community nursing in Australia 1995-2000. Journal of Advanced Nursing. 49; 3:307-314.

Malmsten U.H.H., Milsom I., Molander U \& Norlen L.J. (1997) Urinary incontinence and lower urinary tract symptoms: an epidemiological study of men aged 45-99 years. Journal of Urology. 158:1733-37.

Massolt E.T., Wooning M.M., Stijnen T. \& Vierhoult M.E. (2004). Prevalence, impact on the quality of life and pathophysiological determinants of nocturia in urinary incontinence women. International Urogynaecology Journal and Pelvic Floor Dysfunction. 16; 2:132-137.

McDowell J., Engberg S., Rodriguez E. ... (1996) Characteristics of urinary incontinence in homebound older adults. Journal of the American Geriatrics Society. 44:963-968. 
McGrother C.W., Donaldson M.M., Shaw C., Mathews R.J., Dallosso H.M., Jagger C., Clarke M. \& Castleden C.M. (2004) Storage disorder of the bladder: prevalence, incidence and need for services in the UK (MRC study). British Journal of Urology International. 93:763-9.

Melville J.L., Katon W., Delaney K. \& Newton K. (2005) Urinary incontinence in US women: a population based study. Archives of Internal Medicine. 165; 5:537-542.

Milne J.L. \& Moore K.N. (2003) An exploratory study of continence care services worldwide. International Journal of Nursing Studies. 40:235-247.

Moller L.A., Lose G. \& Jorgensen T. (2000) The prevalence and bothersomeness of lower urinary tract symptoms in women 40-60 years of age. Acta Obstetricia et Gynaecologica Scandinavica. 79; 4:298-305.

O’Brien J, Austin M, Sethi P. \& O’Boyle P. (1991) Urinary incontinence. Prevalence, need for treatment and effectiveness of interventions by nurses. British Medical Journal 303; 1308-1312

O'Dowd T.C. (1993). Management of urinary incontinence in women. British Journal of General Practice. 43; 375:426-9.

Olver L. \& Buckinham K. (1997). Analysis of district nurse workload in the community. British Journal of Community Health Nursing. 2; 3:127-134.

Perry S., Shaw C., Assassa P., Dallossa H., William K., Brittain K.R., Mensah F., Smith N., Clarke M., Jagger C., Mayne C., Casleden C., Jones J., McGrother C. \& the Leicestershire 
MRC Incontinence Study Team. (2000). An epidemiological study to establish the prevalence of urinary symptoms and felt need in the community: the Leicestershire MRC Incontinence Study. Journal of Public Health Medicine. 22; 3: 427-34.

Peters T.J., Donovan J.L., Kay H.E., Abrams P., de la Rosette J.J., Porru D. \& Thuroff J.W. (1997). The international Continence Society "Benign Prostatic Hyperplasia" Study: The bothersomeness of urinary symptoms. The Journal of Urology. 157; 3:885-889.

Peters T.J., Horrocks S., Stoddart H. \& Somerset M. (2004) Factors associated with variations in older people's use of community cased continence services. Health \& Social Care in the Community. 12; 1:53-62.

Roberts R.O., Jacobsen S.J., Rhodes T., Reilly T.W., Girman C., Talley N. \& Limber M. (1998). Urinary incontinence in a community-based cohort: prevalence and health seeking behaviour. American Geriatrics Society. 46;4:467-472.

Roe B., Doll K. \& Wilson K. Help seeking behaviour and health and social services utilisation by people suffering from urinary incontinence. (1999) International Journal of Nursing Studies. 36; 3: 245-53.

Rout U. (2000) Stress amongst district nurses: a preliminary investigation. Journal of Clinical Nursing. 9:303-9. 
Sandvik H., Hunskaar S., Seim A., Hernstad R., Vanvik A. \& Bratt H. (1993). Validation of a severity index in female urinary incontinence and its implementation in an epidemiological survey. J. Epidemiological Community Health. 47:497-9.

Shaw C., Matthews R.J., Perry SI., Williams K., Spiers N., Assassa R.P., McGrother C., Dallosso H., Jagger C., Mayne C., Clark M. \& Leicestershire MRC incontinence team.(2004). Validity and reliability of a questionnaire to measure the impact of lower urinary tract symptoms on quality of life: The Leicester Impact Scale. Neurourology \& Urodynamics. 23; 3:229-36.

Shaw C., Matthews R.J., Perry SI., Assassa R.P., Williams K., McGrother C., Dallosso H., Jagger C., Mayne C., Clarke M. \& the Leicestershire MRC Incontinence team.(2002) Validity and reliability of an interviewer-administered questionnaire to measure severity of lower urinary tract symptoms of storage abnormality: the Leicestershire Urinary Symptoms Questionnaire. British Journal of Urology International. 90:205-15.

Shaw C. (2001) A review of the psychosocial predictors of help-seeking behaviour and impact on quality of life in people with urinary incontinence. Journal of Clinical Nursing. 10; $1: 15-24$

Shaw C., Tansey R., Jackson C., Hyde C. \& Allan R. (2001) Barriers to help seeking in people with urinary symptoms. Family Practice. 18; 1:48-52.

Stewart M., Moore M., May F., Marks R. \& Hale W. (1992) Nocturia: a risk for falls in the elderly. Journal of the American Geriatrics Society. 40:1217-20. 
Swithinbank L.V., Vestey S., Abrams P. (2004) Nocturnal polyuria in community dwelling women. British Journal of Urology International. 4:523-552.

Swithinbank L.V. \& Abrams P. (2000). A detailed description, by age, of lower urinary tract symptoms in a group of community dwelling women. British Journal of Urology International. 85; Suppl. 2: 19-24.

Teunissen D. \& Lagro-Janssen T. Urinary incontinence in community dwelling elderly: are there sex differences in help-seeking behaviour. Scandinavian J. Primary Health Care. 22:209-216.

Thom D.H. (1998) Variations in estimates of urinary incontinence prevalence in the community: effects of differences in definition, population characteristics and study type. Journal of the American Geriatric Society. 46: 473-480.

Thomas T.M., Plymat K.R., Blannin J. \& Meade T.W. (1980) Prevalence of urinary incontinence. British Medical Journal. 281:1243-46.

Turner D.A., Shaw C., McGrother C.W., Dallosso H.M., Cooper N.J. \& the MRC Incontinence Team. (2004). The costs of clinically significant urinary storage symptoms for community dwelling adults in the UK. British Journal of Urology International. 93:1246-51. 
St. John W., James H. \& McKenzie S. (2002) "Oh that's a bit of a nuisance": communitydwelling clients' perspectives of urinary continence health care provision. Journal of Wound,Ostomy and Continence Nursing. 29; 6:312-9.

Umlauf M.G., Goude S. \& Burgio K.L. (1996) Psychosocial issues in geriatric urology: problems in treatment and treatment seeking. Urologic Clinics of North America. 23; 1:12736.

Viktrup P., Summers KL., Dennett SL. (2004) Clinical practice guidelines for the initial management of urinary incontinence in women: a European focused review. British Journal of Urology. 94:14-20.

Wagg A., Mian S., Lowe D. \& Potter J. (2005) Report of the national audit of continence care for older people (65 years and above) in England, Wales and Northern Ireland. Clinical Effectiveness and Evaluation Unit. Royal College of Physicians. London.

Wagg A. (2004) Urinary Incontinence-older people: where are we now? British Journal of Obstetrics \& Gynaecology. 111; 1:15-19.

Watson N.M., Brink C.A., Zimmer J.G.\& Mayer R.D. (2003). Use of the Agency for Health Care Policy and Research Urinary Incontinence Guidelines in Nursing Homes. Journal of the American Geriatrics Society. 51; 12:1779-1786. 
Williams K., Assassa R., Smith N., Rippin C., Shaw C., Mayne C. (2002) Continence management. Good practice in continence care: development of a nurse-led service. British Journal of Nursing. 11; 8: 548, 550, 552-9.

Wilson S., Delaney B., Roalfe L., Redman V., Wearn A, Hobbs F. (2000) Randomised controlled trials in primary care: case study. British Medical Journal, 321;24-27. 
- Stress Urinary Incontinence

In the last month has any urine leaked when you laugh, cough, sneeze or exercise?

- Urge Urinary Incontinence

In the last month have you felt such a strong desire to pass urine that you leaked before reaching the toilet?

- Voiding disorder

In the last month have you leaked urine without feeling it happening or realising?

- "Functional" UI

In the last month have you leaked urine because you had difficulty getting to, or getting on or off, a toilet or commode?

- Nocturia

How often do you feel the need to get up at night to pass urine usually?

3 or more times a night

Twice a night

Once a night

Not Usually

In the last month have you leaked urine when you did not mean to during the day (this means anything from a few drops to a flood)?

Continuously

Several times a day (more than once or twice)

1 or 2 times a day

Several times a week (more than once or twice)

1 or 2 times a week

Several times in the last month (more than once or twice)

1 or 2 times in the last month

Not incontinent in the last month

*(Based on ICS Symptom definitions, Abrams et al, 2002) 
Table 1: Patient Characteristics $(\mathbf{n}=999)$

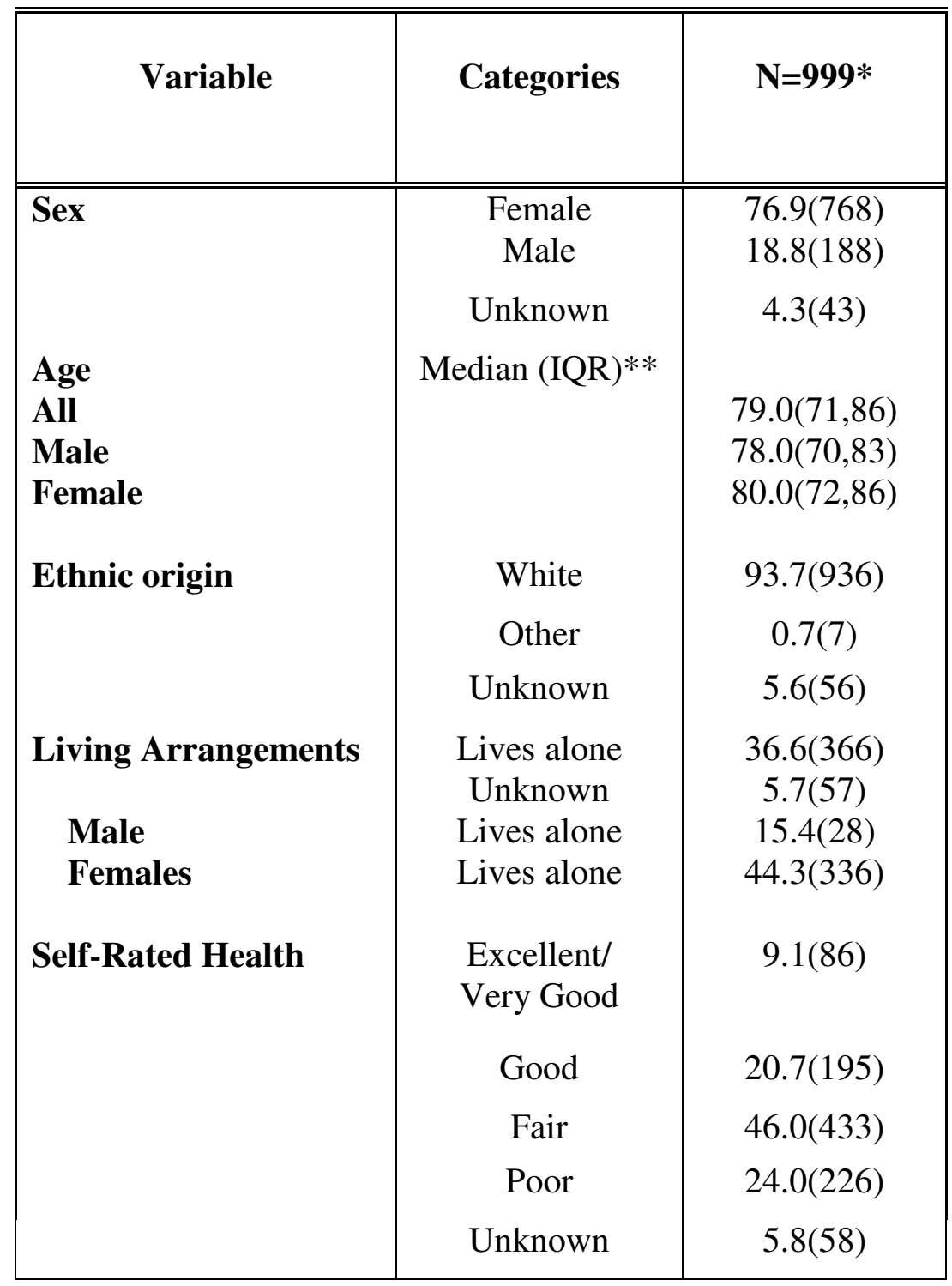

Figures reported are \% (n) unless otherwise stated

* Total sample $n=999$ (data missing on gender of 43 respondents)

**inter quartile range 
Table 2: Duration and Nature UI Symptoms

\begin{tabular}{|c|c|c|c|c|c|}
\hline Variable & Categories & $\begin{array}{r}\text { Total Sample } \\
\%(\mathrm{~N}=999 \dagger) \\
\end{array}$ & $\begin{array}{r}\text { Females } \\
\%(\mathrm{~N}=768)\end{array}$ & $\begin{array}{r}\text { Males } \\
\%(\mathrm{~N}=188) \\
\end{array}$ & p-value \\
\hline Duration of UI* & $\begin{array}{l}\text { Less than } 1 \text { year } \\
1 \text { to } 5 \text { years } \\
\text { More than } 5 \text { years } \\
\text { Missing }\end{array}$ & $\begin{array}{c}15.6(144) \\
48.0(442) \\
36.4(335) \\
7.8(78)\end{array}$ & $\begin{array}{l}14.0(104) \\
48.5(361) \\
36.5(280) \\
3.0(23)\end{array}$ & $\begin{array}{l}23.1(40) \\
45.1(78) \\
31.8(55) \\
7.9(15)\end{array}$ & $\mathrm{p}=0.009$ \\
\hline $\begin{array}{l}\text { In the last month have you } \\
\text { leaked urine when you didn't }\end{array}$ & $\begin{array}{l}\text { Continuously/several times a } \\
\text { day }\end{array}$ & $63.9(578)$ & $64.1(463)$ & $63.4(109)$ & $\mathrm{p}=0.194$ \\
\hline & $\begin{array}{l}\text { Several times a week } \\
\text { Several times in the last } \\
\text { month } \\
\text { Not incontinent in last month } \\
\text { Missing }\end{array}$ & $\begin{array}{c}15.6(141) \\
13.7(124) \\
6.6(60) \\
10.4(94)\end{array}$ & $\begin{array}{l}16.6(120) \\
13.6(98) \\
5.7(41) \\
6.0(46)\end{array}$ & $\begin{array}{c}11.6(20) \\
14.5(25) \\
10.5(18) \\
16(8.5)\end{array}$ & \\
\hline Stress UI * & $\begin{array}{l}\text { In last month } \\
\text { Missing }\end{array}$ & $\begin{array}{l}65.7(653) \\
10.5(105)\end{array}$ & $\begin{array}{l}71.7(512) \\
7.0(54)\end{array}$ & $\begin{array}{l}46.8(80) \\
9.0(17)\end{array}$ & $\mathrm{p}<0.001$ \\
\hline Urge UI * & $\begin{array}{l}\text { In last month } \\
\text { Missing }\end{array}$ & $\begin{array}{l}75.6(751) \\
10.6(106)\end{array}$ & $\begin{array}{l}86.3(617) \\
6.9(53)\end{array}$ & $\begin{array}{c}74.8(125) \\
10.6(21)\end{array}$ & $\mathrm{p}=0.01$ \\
\hline Voiding Disorder & $\begin{array}{l}\text { In last month } \\
\text { Missing }\end{array}$ & $\begin{array}{l}60.5(549) \\
9.2(92)\end{array}$ & $\begin{array}{l}59.8(435) \\
5.3(41)\end{array}$ & $\begin{array}{l}65.3(111) \\
9.6(18)\end{array}$ & $\mathrm{p}=0.163$ \\
\hline Functional UI* & $\begin{array}{l}\text { In last month } \\
\text { Missing }\end{array}$ & $\begin{array}{l}64.2(577) \\
10.0(100)\end{array}$ & $\begin{array}{l}66.3(479) \\
5.8(45)\end{array}$ & $\begin{array}{l}50.0(94) \\
11.1(21)\end{array}$ & $\mathrm{p}=0.014$ \\
\hline $\begin{array}{l}\text { In the last month when you } \\
\text { leaked urine were you*: }\end{array}$ & Soaked & $23.3(210)$ & $16.2(177)$ & $19.1(33)$ & $\mathrm{p}=0.001$ \\
\hline & $\begin{array}{l}\text { Wet (pad or under clothing } \\
\text { wet) } \\
\text { Damp } \\
\text { Almost dry } \\
\text { Not applicable } \\
\text { Missing }\end{array}$ & $\begin{array}{l}41.5(374) \\
26.9(243) \\
4.1(37) \\
4.2(38) \\
9.7(97)\end{array}$ & $\begin{array}{l}42.9(310) \\
25.8(186) \\
3.6(26) \\
3.2(23) \\
6.0(46)\end{array}$ & $\begin{array}{l}36.1(62) \\
30.8(53) \\
5.8(10) \\
8.1(14) \\
8.5(16)\end{array}$ & \\
\hline Severity of Daytime UI $\dagger \dagger$ & $\begin{array}{l}\text { Slight (1-2) } \\
\text { Moderate (3-4.5) } \\
\text { Severe (6-8) } \\
\text { Missing }\end{array}$ & $\begin{array}{l}11.4(96) \\
27.8(234) \\
60.8(511) \\
15.8(158)\end{array}$ & $\begin{array}{l}11.0(75) \\
26.1(178) \\
62.9(429) \\
11.2(86)\end{array}$ & $\begin{array}{l}13.1(20) \\
34.2(52) \\
52.7(80) \\
19.1(36)\end{array}$ & $\mathrm{p}=0.548$ \\
\hline Severity of night-time $\mathrm{UI} \dagger \dagger$ & $\begin{array}{l}\text { Slight }(1-2) \\
\text { Moderate (3-4.5) } \\
\text { Severe (6-8) } \\
\text { Missing }\end{array}$ & $\begin{array}{l}25.0(205) \\
23.9(196) \\
51.1(419) \\
17.9(179)\end{array}$ & $\begin{array}{l}28.1(186) \\
19.9(132) \\
52.0(345) \\
13.7(105)\end{array}$ & $\begin{array}{l}12.2(15) \\
29.1(36) \\
58.5(72) \\
34.6(65)\end{array}$ & $\mathrm{p}=0.185$ \\
\hline $\begin{array}{l}\text { Nocturia* } \\
\text { (how often do you feel the } \\
\text { the need get up at night } \\
\text { to pass urine usually?) }\end{array}$ & $\begin{array}{l}\text { Not usually } \\
\text { Once a night } \\
\text { Twice a night } \\
3 \text { or more times a night } \\
\text { Missing }\end{array}$ & $\begin{array}{c}8.9(81) \\
16.2(148) \\
33.8(308) \\
41.1(375) \\
8.7(87)\end{array}$ & $\begin{array}{c}8.5(65) \\
16.9(130) \\
34.2(263) \\
37.0(284) \\
3.4(26)\end{array}$ & $\begin{array}{l}13.37(22) \\
9.6(16) \\
26.5(44) \\
53.6(89) \\
11.7(22)\end{array}$ & $\mathrm{p}=0.016$ \\
\hline $\begin{array}{l}\text { Frequency } \\
\text { (how often do you go to the } \\
\text { toilet to pass urine in the } \\
\text { day time usually?) }\end{array}$ & $\begin{array}{l}3 \text { hours or more } \\
2 \text { hours } \\
1 \text { hour } \\
\text { Half hour } \\
\text { Missing }\end{array}$ & $\begin{array}{c}22.6(204) \\
42.5(383) \\
24.8(223) \\
10.1(91) \\
9.8(98)\end{array}$ & $\begin{array}{c}21.1(162) \\
43.0(314) \\
25.0(183) \\
9.8(72) \\
4.8(37)\end{array}$ & $\begin{array}{l}25.1(42) \\
39.8(66) \\
24.0(40) \\
10.8(18) \\
11.7(22)\end{array}$ & $\mathrm{p}=0.794$ \\
\hline
\end{tabular}

† Total sample $n=999$ (data missing on gender of 43 respondents)

$\dagger \dagger$ Sandvick index frequency of UI x volume of urine loss (Sanvick et al, 1993) 
Table3: $\quad$ Impact of UI symptoms on Aspects of Quality of Life

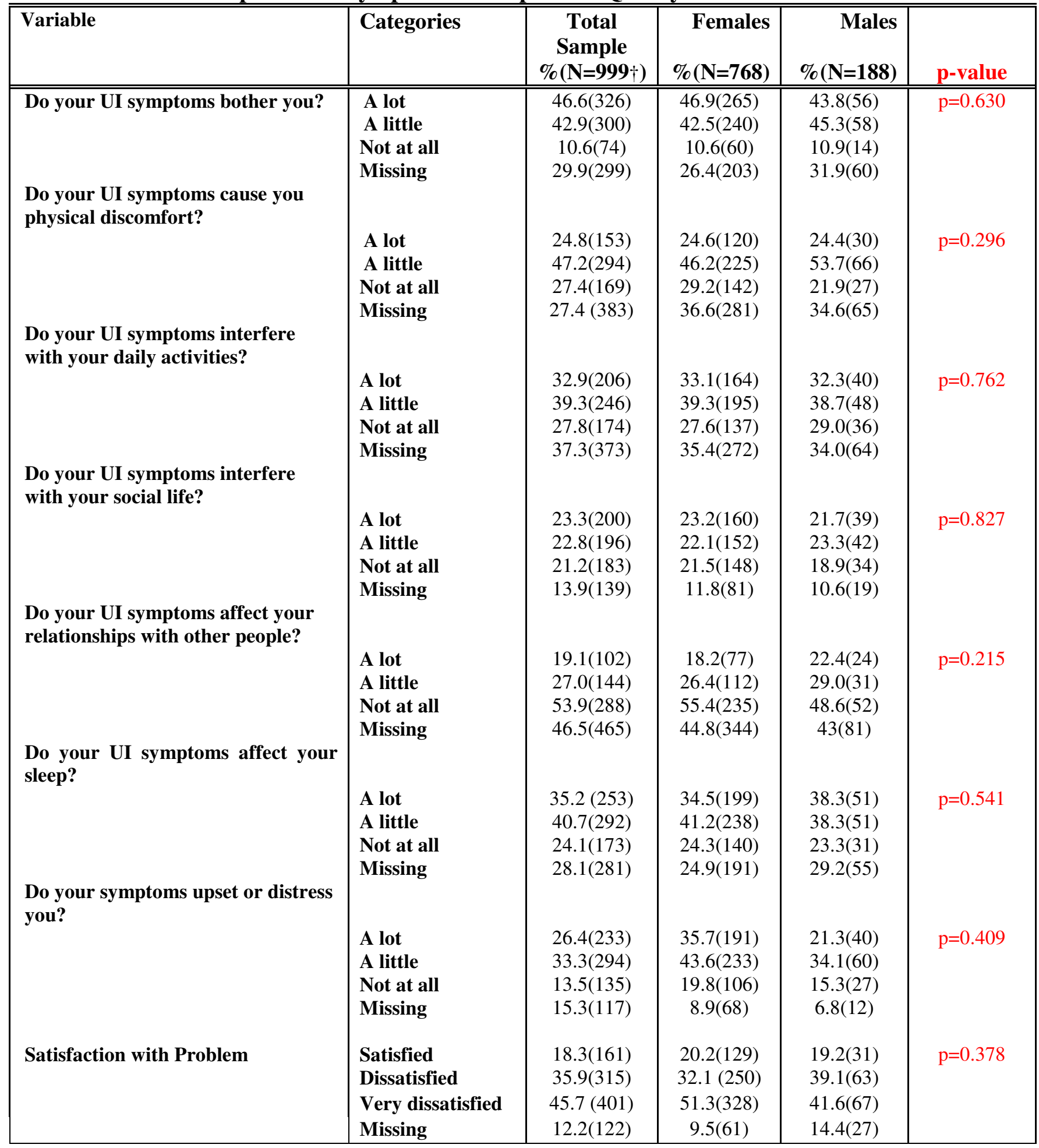

†Total sample $\mathrm{n}=999$ (data missing on gender of 43 respondents) 
Table 4: $\quad$ Sources of Support for Coping with UI symptoms (n=999)

\begin{tabular}{|c|c|c|c|c|c|}
\hline Variable & Categories & $\begin{array}{r}\text { Total Sample } \\
\%(\mathrm{~N}=999 \dagger)\end{array}$ & $\begin{array}{r}\text { Females } \\
\%(\mathrm{~N}=768)\end{array}$ & $\begin{array}{r}\text { Males } \\
\%(\mathrm{~N}=188) \\
\end{array}$ & p-value \\
\hline Partner/spouse* & $\begin{array}{l}\text { A little } \\
\text { A lot } \\
\text { Not at all } \\
\text { Not Applicable } \\
\text { Unknown }\end{array}$ & $\begin{array}{c}5.2(42) \\
27.2(221) \\
4.8(39) \\
509(62.7) \\
18.9(188)\end{array}$ & $\begin{array}{r}4.8(31) \\
20.5(132) \\
5.6(36) \\
68.7(442) \\
16.3(125)\end{array}$ & $\begin{array}{c}6.5(11) \\
52.4(88) \\
1.8(3) \\
11.9(20) \\
10.6(20)\end{array}$ & $\mathrm{p}<0.001$ \\
\hline Family & $\begin{array}{l}\text { A little } \\
\text { A lot } \\
\text { Not at all } \\
\text { Not Applicable } \\
\text { Unknown }\end{array}$ & $\begin{array}{c}12.8(105) \\
27.3(224) \\
8.7(71) \\
51.3(422) \\
17.7(177)\end{array}$ & $\begin{array}{r}13.6(89) \\
27.7(182) \\
7.2(55) \\
50.3(330) \\
14.6(112)\end{array}$ & $\begin{array}{c}9.1(15) \\
25.0(41) \\
9.8(16) \\
56.0(92) \\
12.8(24)\end{array}$ & $\mathrm{p}=0.679$ \\
\hline General Practitioner & $\begin{array}{l}\text { A little } \\
\text { A lot } \\
\text { Not at all } \\
\text { Not Applicable } \\
\text { Unknown }\end{array}$ & $\begin{array}{c}19.0(154) \\
21.7(176) \\
10.2(83) \\
49.1(399) \\
18.7(187)\end{array}$ & $\begin{array}{l}18.0(116) \\
20.3(131) \\
10.7(69)) \\
42.7(328) \\
16.1(124)\end{array}$ & $\begin{array}{c}22.2(37) \\
26.5(44) \\
8.4(14) \\
42.7(71) \\
11.7(22)\end{array}$ & $\mathrm{p}=0.150$ \\
\hline Nurse & $\begin{array}{l}\text { A little } \\
\text { A lot } \\
\text { Not at all } \\
\text { Not Applicable } \\
\text { Unknown }\end{array}$ & $\begin{array}{c}25.2(228) \\
52.6(477) \\
3.1(28) \\
19.1(173) \\
9.3(93)\end{array}$ & $\begin{array}{r}25.4(183) \\
52.0(375) \\
3.3(24) \\
19.2(139) \\
6.1(47)\end{array}$ & $\begin{array}{c}24.7(44) \\
53.9(96) \\
2.2(4) \\
19.0(34) \\
5.3(10)\end{array}$ & $\mathrm{p}=0.481$ \\
\hline $\begin{array}{l}\text { Specialist nurse } \\
\text { /Continence advisor }\end{array}$ & $\begin{array}{l}\text { A little } \\
\text { A lot } \\
\text { Not at all } \\
\text { Not Applicable } \\
\text { Unknown }\end{array}$ & $\begin{array}{c}9.7(79) \\
20.2(165) \\
7.9(64) \\
62.2(507) \\
18.4(184)\end{array}$ & $\begin{array}{c}9.3(61) \\
20.0(131) \\
8.9(58) \\
61.7(402) \\
15.1(116)\end{array}$ & $\begin{array}{c}11.6(18) \\
22.1(34) \\
3.9(6) \\
67.5(104) \\
18.1(34)\end{array}$ & $\mathrm{p}=0.113$ \\
\hline
\end{tabular}

†Total sample $\mathrm{n}=999$ (data missing on gender of 43 respondents) 